\title{
Toledo, locus terribilis. Iglesia y milagro en el De viris illustribus de Ildefonso de Toledo
}

\author{
Toledo, locus terribilis. Church and Miracles in the De viris illustribus \\ of Ildefonsus of Toledo
}

Dolores CASTRO

Universidad de Buenos Aires

doloresdice@gmail.com

Recibido: 03/03/2015

Aceptado: 18/05/2015

\section{RESUMEN}

A mediados del siglo VII, el obispo Ildefonso de Toledo (657-667) elaboró su propio catálogo de hombres ilustres, continuando una tradición cuyos orígenes cristianos se remontaban a Jerónimo en el siglo IV. Sin embargo, en lugar de reproducir los modelos de sus antecesores cristianos, entre los que se incluyen además a Genadio de Marsella e Isidoro de Sevilla, el De viris illustribus de Ildefonso incorporaba cambios significativos en el género. Este artículo estudia el tópico del milagro en el opúsculo toledano con el objetivo de indagar qué tipo de relación estableció la Iglesia visigoda de la segunda mitad del siglo VII con este tipo de fenómenos y qué estrategias elaboró en función de él.

Palabras clave: iglesia, milagro, Toledo, Visigodos.

\begin{abstract}
In the mid-seventh century, Bishop Ildefonsus of Toledo (657-667) wrote his own catalogue of illustrious men, continuing the Christian tradition initiated by Jerome in the fourth century. However, far from imitating the models of his Christian predecessors (Jerome, Gennadius of Marseilles, and Isidore of Seville), the work of the Toledan bishop De viris illustribus incorporated significant changes in the genre. This article studies the topic of miracles in the Toledan catalogue in order to analyse the midseventh century Visigothic church's stance on miraculous phenomena and to examine the strategies it developed in consequence.
\end{abstract}

Key Words: Church, Miracles, Toledo, Visigoths.

Sumario: 1. Ildefonso de Toledo y la tradición de un género. 2. Miraculum, signum, virtus. 2.1. Toledo, locus terribilis. 2.2. ¿Un escenario de santos? 3. La capitalización episcopal del milagro. 3.1. Presente. 3.2. Futuro. 4. Conclusiones. 5. Fuentes. 6. Bibliografía. 
Recientemente, los estudios acerca del milagro en la Antigüedad Tardía y la Edad Media conocieron un notable desarrollo debido, en parte, a los trabajos publicados por el historiador Peter Brown ${ }^{1}$ en el último tercio del siglo XX. La aparición en 1971 de su artículo titulado "The Rise and Function of the Holy Man in Late Antiquity" significó el comienzo de una serie de estudios que, sin desconocer la tradición historiográfica anterior, instalaron nuevos interrogantes y perspectivas en el campo. La propuesta inicial de Brown, centrada en la función social del hombre santo, indagaba principalmente la posición de esta figura dentro de la comunidad en la que vivía y actuaba, es decir, dentro del contexto socio-económico en el cual se hallaba inmersa. Posteriormente, su investigación avanzó hacia otros derroteros: el control del culto a los santos, el traslado de reliquias y la construcción de la autoridad. Estos nuevos rumbos permitieron indagar con mayor precisión la relación de aquella compleja figura con su entorno cultural. De patronus a mediador de lo sagrado, el hombre santo se convirtió en adelante en protagonista indiscutible de las sociedades cristianas tardoantiguas.

A partir de estas primeras incursiones, especialmente en el terreno hagiográfico, nuevos análisis retomaron las líneas de investigación propuestas y permitieron complejizar tanto el papel desempeñado por estos sujetos como los contextos históricos en los que vivieron y desarrollaron sus actividades ${ }^{2}$. En efecto, las últimas décadas del siglo XX asistieron a una renovación de los estudios hagiográficos gracias al desarrollo de nuevas perspectivas como también a los avances producidos en el campo filológico. Entre las principales tendencias destacan las investigaciones en torno al culto a los santos y la Biblia ${ }^{3}$, la concepción medieval del milagro ${ }^{4}$, la topografía sagrada $^{5}$ y la construcción de formas de liderazgo ${ }^{6}$, entre otras. En este marco, el horizonte geográfico demostró un renovado y amplio alcance; de Oriente a Occidente, el hombre santo diseminó su carisma forjando vínculos de distinta naturaleza con las instituciones y actores sociales que coexistieron, actuaron e intervinieron en los distintos contextos históricos.

En este artículo propongo analizar la economía de poder que se articula en torno a la capacidad carismática de obrar milagros en un marco espacio-temporal específico, el reino visigodo de Toledo, con el objetivo de indagar qué tipo de relación forjó la Iglesia visigoda de la segunda mitad del siglo VII con el don carismático y qué es-

${ }^{1}$ Brown, "The rise and function of the Holy Man in Late Antiquity"; IDEM, The cult of the saints; IDEM, Society and the holy in Late Antiquity; IDEM, Authority and the sacred in Late Antiquity.

${ }^{2}$ Cf. Howard-Johnston, Hayward Paul (eds.), The cult of saints in Late Antiquity and the Middle Ages.

${ }^{3}$ UytFAnGHe, "La Bible dans les Vies de saints mérovingiennes".

${ }^{4}$ WARD, Miracles and the medieval mind.

${ }^{5}$ Lauwers, "Le cimetière dans le Moyen Âge latin. Lieu sacré, saint et religieux"; KaPLAN, Le sacré et son inscription dans l'espace à Byzance et en Occident: Études comparées.

${ }^{6}$ DAM, Leadership and community in Late Antique Gaul; RAPP, Holy Bishops in Late Antiquity. The nature of christian leadership in an age of transition. 
trategias elaboró en función de él. El texto a examinar será el De viris illustribus ${ }^{7}$ de Ildefonso de Toledo, obispo de la ciudad regia entre los años 657 y $667^{8}$.

El título de la obra estudiada nos remite necesariamente a un género cuya vertiente cristiana había sido iniciada en el siglo IV por Jerónimo de Estridón, continuada un siglo más tarde por Genadio de Marsella y retomada por Isidoro de Sevilla en tiempos del reino visigodo de Toledo. Por lo tanto, cuando Ildefonso menciona en el prefacio las obras de estos tres autores, demuestra conocer la tradición que lo precede. Sin embargo, lejos de acoplar su escritura a los modelos establecidos desde antaño, el prelado toledano incorpora en su obra significativos cambios. Uno de ellos, la introducción del milagro, será sin lugar a duda un aporte novedoso, puesto que la presencia de relatos milagrosos había sido hasta el momento un rasgo típico del género hagiográfico, limitado en Hispania a un conjunto harto reducido de obras entre las que destacan la Vita Desiderii ${ }^{9}$ (ca. 613), la Vita Aemiliani (ca. 636) de Braulio de Zaragoza y las Vitae sanctorum patrum Emeritensium (ca. 633).

A lo largo del siglo VII las elites eclesiásticas visigodas modificaron considerablemente su posición frente al hecho milagroso, su valoración y modo de empleo ${ }^{10}$. En este sentido, en la obra del obispo toledano se advierte una reformulación de la actitud hacia este tipo de fenómenos, más abierta y receptiva, postura que contó con antecedentes en importantes personalidades visigodas, como el ya mencionado obispo de Zaragoza. En rigor, la adopción de una visión permeable al milagro se inscribe en un período de elaboración de nuevas estrategias por parte de una Iglesia que busca apropiarse de la experiencia milagrosa y utilizarla a su favor dentro de un contexto en el que proliferan en paralelo otras formas de encarar la vida religiosa y la perfección espiritual en el interior del reino.

Desde esta perspectiva, a diferencia de un Isidoro de Sevilla, Ildefonso introduce el milagro en el presente de la Iglesia visigoda, en particular en la sede episcopal de Toledo, y lo deposita en manos de su más alta jerarquía: los obispos. En este sentido, el metropolitano hace uso de aquel expediente en función de unos fines -de carácter político- bien definidos, y, de este modo, inclina a su favor toda la potencia del fenómeno milagroso.

\footnotetext{
${ }^{7}$ A pesar de no conocerse una fecha exacta de producción, la obra fue probablemente elaborada durante el episcopado de Ildefonso, entre los años 657 y 667 . En el mismo período, Ildefonso compuso otro tratado, De cognitione baptismi y su complemento De itinere deserti, del cual tampoco se conoce una datación precisa. Por su parte, la composición del tratado De uirginitate sanctae mariae, una de las obras con mayor repercusión del toledano, dedicada a la encarnación de Cristo y a la maternidad virginal de María, se sitúa en una etapa inmediatamente anterior a la ocupación de la silla episcopal, cuando Ildefonso ocupó el cargo de abad en el monasterio de Agali.

${ }^{8}$ En este trabajo seguimos la edición elaborada por Carmen Codoñer Merino (2007). Las citas en español corresponden a la traducción de la misma autora (1972).

${ }^{9}$ La Vita Desiderii es la primera hagiografía visigoda que se conoce. A diferencia de las restantes, es la única elaborada por un rey, el rey Sisebuto, quien ocupó el trono visigodo entre los años 612 y 621 .

10 Para un estudio exhaustivo de este recorrido, véase: Dell'Elicine, En el principio fue el Verbo, pp. 197-222.
} 


\section{ILDEFONSO DE TOLEDO Y LA TRADICIÓN DE UN GÉNERO}

Es sabido que el De viris illustribus de Ildefonso de Toledo introdujo transformaciones fundamentales respecto de sus predecesores en el género. Si tenemos en cuenta únicamente la tradición cristiana, los orígenes se remontan a Jerónimo de Estridón en el siglo IV ${ }^{11}$. En efecto, su catálogo había sido elaborado con la finalidad de ofrecer una lista de noticias breves sobre escritores, en su gran mayoría cristianos, desde Cristo hasta la primera década del reinado de Teodosio. Por lo tanto, como destaca Carmen Codoñer, cristianismo y escritura constituyeron los principales criterios de inclusión seleccionados en su obra ${ }^{12}$. Ahora bien, las condiciones exigidas por Jerónimo obedecían a un interés específico, el de demostrar ante sus adversarios paganos la existencia dentro de la Iglesia cristiana de un número más o menos extenso de hombres que efectivamente se habían dedicado a la escritura y al cultivo de las letras.

A Jerónimo lo siguió Genadio de Marsella, quien elaboró su propio catálogo alrededor del año 480. En este nuevo contexto la causa que motoriza la escritura no es ya la cuestión pagana, sino la situación en el interior del cristianismo. Con Genadio se advierten ya algunas modificaciones en el género, como el protagonismo de personajes vinculados al ámbito monástico y la reducción del alcance geográfico, operación que será profundizada por los continuadores peninsulares en el siglo VII: Isidoro de Sevilla e Ildefonso de Toledo ${ }^{13}$.

Con Isidoro se mantienen intactos dos rasgos típicos de la obra de Jerónimo: la objetivación y la despersonalización ${ }^{14}$. Es decir, no hay en el catálogo isidoriano lugar para la anécdota o la valoración personal, pero sí se constata la inclusión de un número mayor de escritores procedentes de Hispania ${ }^{15}$. En este sentido, los trabajos de Jamie Wood han destacado que el principal objetivo del De viris isidoriano (y también ildefonsiano) consistió en exaltar la autoridad de la Iglesia visigoda, en particular

${ }^{11}$ A propósito de la tradición pagana del género, Jamie Wood sostiene: "The tradition of writing about the lives of famous men was an ancient one with firm roots in classical antiquity. Jerome explicitly associated his De viris illustribus, the earliest Christian text of this sort, written in 393, with the Greco-Latin biographical tradition. The second-century author Suetonius was an avid writer of biographies. His most famous work, De vita Caesarum, contained biographies of twelve Roman rulers from Caesar to Domitian". Wood, "Playing the fame game", p. 615.

${ }^{12}$ Cf. Codoñer, "Los De viris illustribus en la Hispania visigótica”, p. 246. Y agrega más adelante: “... los hombres han sido seleccionados por su adscripción a una ideología, no a una profesión, y son ilustres por el simple hecho de haber escrito algo, siempre que lo hayan hecho desde el punto de vista doctrinal." Ibidem, p. 247.

13 "Earlier Christian texts on famous men had not really focused on Spain. Jerome had written about only nine Spaniards out of 135, while Gennadius mentioned only five Spaniards out of 101. Both the Christianity and the illustriousness of several members of this collection were in some doubt. For example, two of Jerome's famous Spanish men are the Younger Seneca (d. 65), a pagan Roman philosopher, and Priscillian (d. 385), a heretic. Two followers of Priscillian, Latronianus and Tiberianus, provide further padding to Jerome's list, while Gennadius includes Vigilantius, another Spanish heretic". Wood, "Playing the fame game", p. 623.

${ }^{14}$ Cf. CODOÑER, "El «De viris illustribus» de Ildefonso", p. 489.

15 "Isidoro, por su parte, aunque también se propone completar la historia literaria iniciada por sus ilustres antecesores, aspira sobre todo a demostrar que la Península Ibérica puede equipararse en el terreno cultural a cualquier otra región de la cristiandad, ya sea de habla latina o griega. Así, de las 33 noticias que constituyen el tratado isidoriano, más de un tercio de ellas, 12 en total, están dedicadas a autores hispanos o activos en Hispania (Martín de Braga)". MARTIN, "El catálogo de los varones ilustres de Isidoro de Sevilla (CPL 1206): contenidos y datación", p. 130. 
frente a Roma y Constantinopla, mediante la incorporación de noticias de escritores peninsulares ${ }^{16}$. Asimismo, según el autor, ambas obras constituyen expresiones de un proceso de regionalización acentuado en la península y de la competencia entre las distintas ciudades y sedes episcopales de la Hispania del siglo VII.

Finalmente, en el cuarto y último lugar, el De viris illustribus de Ildefonso de Toledo. Más allá de las referencias formales que inscriben al obispo toledano dentro de la tradición del género como el último eslabón de una cadena de personalidades eclesiásticas reconocidas, Ildefonso no presenta un acusado interés en las obras de sus antecesores ${ }^{17}$. Por el contrario, se muestra verdaderamente interesado en advertir el carácter incompleto de la obra isidoriana, la más cercana temporal y espacialmente $^{18}$. En rigor, esta valoración se vincula con la ausencia en el escrito del hispalense de viri illustres procedentes de Toledo. En este sentido, la transformación que opera en el De viris ildefonsiano es contundente: de los trece personajes que integran su catálogo, siete son toledanos.

Como anotamos, Ildefonso introduce en su De viris cambios de gran envergadura que dotan a su catálogo de elementos novedosos, ausentes en los escritos previos. En particular, se advierte un cambio de finalidad y una transformación del concepto de "hombre ilustre". En este nuevo marco, la introducción del milagro cumple un papel fundamental al distinguir el escrito ildefonsiano de los restantes cultivadores del género. A diferencia de Isidoro de Sevilla, quien en treinta y tres noticias registró solamente un milagro, Ildefonso lo incorpora de inmediato tanto en los episodios que narra en el prefacio como en las noticias que componen el resto de la obra. Este desplazamiento no sólo indica el protagonismo y repercusión alcanzados por este tipo de fenómenos en la época; al mismo tiempo, advierte sobre formas específicas de lidiar con el hecho milagroso que responden a objetivos definidos, elaborados desde la jerarquía eclesiástica toledana.

\section{MIRACULUM, SIGNUM, VIRTUS}

En la Edad Media, el milagro significó un conjunto de experiencias disímiles, incapaces de responder o ser agrupadas bajo una sola definición o término. Esta ambigüedad, como destaca Alain Dierkens, respondía principalmente a tres factores. En primer lugar, a una suerte de continuidad con la antigüedad clásica, donde seres sobrenaturales habían intervenido constantemente en la vida cotidiana de los hombres sin

${ }^{16}$ Cf. Wood, "Playing the fame game", p. 626-628.

${ }^{17}$ En palabras de C. Codoñer: "El criterio que Ildefonso tiene formado sobre los catálogos de Jerónimo, Genadio e Isidoro, queda al descubierto cuando unifica tácitamente a los tres autores, al describir la obra del primero de ellos. Así, (...) tomando como base la obra de Jerónimo, que parece haber leído, da una descripción puramente formal y externa de las características del género.” Ibidem, p. 490. A propósito de la relación del De viris illustribus de Ildefonso con sus antecesores en el género, véase también: FonTAINE, "El De viris illustribus de san Ildefonso de Toledo", pp. 59-96; GALÁn SÁNCHEZ, "El De viris illustribus de Ildefonso de Toledo", pp. 69-80.

${ }^{18}$ A propósito del tratado isidoriano, Ildefonso sostiene: “Deinceps uir prudentissimus Hispalensis sedis Isidorus episcopus, eodem ductu, quosque uiros optimos reperit in adnotationem subiunxit. Siquidem non omnia perscrutatus abscessit”. ILDEFOnSO DE TOLEDO, De viris illustribus, [en adelante ILDEF, De vir. ill.] praef. 
necesidad o demanda de explicación; en segundo lugar, a las Sagradas Escrituras en donde arraigaban doctrinas diferentes acerca del milagro; finalmente, a la adopción por parte de ciertas autoridades cristianas de una posición escéptica o fuertemente prudente hacia este tipo de fenómenos en la cual se pondera, a los efectos de alcanzar la salvación, la moral, la conducta y la ética ${ }^{19}$.

En la obra de Ildefonso tampoco encontramos un único término para hacer referencia al milagro. En cambio, para indicar o aludir a un hecho milagroso el autor toledano emplea indistintamente cuatro categorías: exemplum, miraculum, signum y virtus.

\subsection{TOLEDO, LOCUS TERRIBILIS}

Los relatos de milagros narrados en el prefacio responden a un objetivo específico vinculado directamente con la ciudad de Toledo, en particular, con la historia de su sede episcopal. Los protagonistas son obispos de la sede toledana y es dentro de ella donde ocurren los distintos fenómenos sobrenaturales. En consecuencia, Toledo es designada sede gloriosa y locus terribilis, y los episodios que introduce el obispo en la primera parte de su obra ofrecen una comprobación de tal afirmación. En este sentido, el milagro constituye un componente fundamental en la construcción de un pasado glorioso que confiere prestigio a la capital del reino visigodo en una coyuntura histórica particular.

Ildefonso diferencia dos tipos de relatos: los que le llegan desde "tiempos muy remotos" (ex antiquitate ueteri) y los "casos actuales" (temporis noui). Como veremos, de las cuatro anécdotas compendiadas en el prefacio sólo la primera es resultado de "un relato antiquísimo y digno de crédito" ${ }^{20}$, mientras que las restantes proceden de un contexto cercano al del obispo. De este modo, al establecer un precedente lejano en el tiempo, Ildefonso advierte que Toledo ha sido lugar de prodigios desde antaño y, de esta manera, brinda credibilidad a los acontecimientos más recientes ${ }^{21}$. Asimismo, el obispo entiende que con el paso del tiempo, algunos sucesos antiguos -y otros recientes- habían sido olvidados y asume el deber de transmitirlos. Se propone así rescatar a la gloriosa sede de Toledo y a sus hombres ilustres del silencio al que habían sido condenados en un tiempo anterior. En otras palabras, su tarea es la de completar el catálogo de viri illustres y subsanar, por medio de la tradición pero también a partir de lo que él mismo había podido observar ${ }^{22}$, la ausencia de representantes toledanos. Por lo tanto, dos criterios, tradición (pasado) y observación (presente), hacen del metropolitano de Toledo la persona adecuada para el ejercicio propuesto. Al mismo tiempo, Ildefonso hace uso de cuanto recurso retórico conoce para que su tarea aparezca ante el lector como un deber necesario, mas indigno de su pluma, un topos

${ }^{19}$ Cf. Dierkens, "Réflexions sur le miracle au haut Moyen Âge", p. 12.

${ }^{20}$ ILDEF, De vir. ill., II: “...antiquissima fidelique relatione narratur...”

${ }^{21}$ Esta operación es reforzada a partir de expresiones que dan cuenta de la previa circulación de los relatos. Algunas de estas fórmulas discursivas son: "se cuenta que..." (ILDEF, De vir. ill., praef), "se dice que..." (ILDEF, De vir. ill., II) o directamente "nos han llegado relatos" (ILDEF, De vir. ill., praef).

${ }^{22}$ ILDEF, De vir. ill., praef: "Horum ego bonorum studiis prouocatus, quaeque uetera antiquorum relata reperi, quaeque noua exhibitione temporis didici, orsu linguae quo potui subnotaui, ut illorum bonae memoriae iungar, a quibus praua operatione disiungor". 2016, vol. 39 49-72 
ya clásico en la literatura cristiana ${ }^{23}$. El soporte elegido para llevar a cabo semejante empresa es la escritura, por medio de la cual el obispo logrará sacar a la luz sucesos anteriormente ignorados. La función de la palabra escrita en el asentamiento de los hechos milagrosos es sumamente significativa, pues contribuye a fijar una forma, una estructura que los despoja del carácter dinámico e inestable propio de relatos orales, cuya circulación involucraba a una audiencia más extensa que el estrecho círculo episcopal visigodo.

Los cuatro acontecimientos enumerados en el prefacio dan cuenta del carácter "terribilis" y "gloriosus" que Ildefonso atribuye a la ciudad de Toledo y a su sede episcopal. El primero de ellos, el más antiguo que le ha llegado a Ildefonso, es el de Montano. Cuenta brevemente que aquel obispo, para demostrar la falsedad de una acusación, sostuvo sobre su traje durante la celebración de una misa carbones encendidos sin que estos perdieran su fuego al finalizar el sacrificio y sin realizarse daño alguno. Con este milagro Montano demostró su inocencia poniendo en evidencia el carácter infundado de la acusación que había sufrido previamente.

A diferencia de Montano, el único milagro de carácter demostrativo, los relatos que le siguen presentan dos rasgos comunes, ausentes en la primera anécdota: en primer lugar, se trata de episodios de insubordinación, en los cuales, con excepción del caso del diácono Justo, el insubordinado cuenta con el respaldo del princeps o de un sector de la nobleza. En segundo lugar, aquel que desobedece a la autoridad episcopal sufre luego el trastorno de los sentidos o la pérdida del control de sus facultades. Los tres ejemplos exhiben un fuerte paralelismo: Justo, a pesar de haber alcanzado la dignidad episcopal, vivió enfermo y trastornados sus sentidos ${ }^{24}$ tras haber insultado al obispo Eladio; en la misma línea, el presbítero Geroncio se enfrentó -con el apoyo del princeps - a otro Justo, el sucesor de Eladio, como resultado de lo cual perdió él también el control de sus facultades; por último, una situación similar padeció otro diácono, Lucidio, luego de su confrontación con Eugenio I, episodio que lo llevó al "trastorno de sus sentidos y a un estado de decaimiento" 25 . En definitiva, en las tres anécdotas se trata de un castigo que reciben los insubordinados como consecuencia de su enfrentamiento con el obispo de Toledo, castigo divino que evoca directamente al Antiguo Testamento. Por otra parte, aunque volveremos más adelante sobre esta cuestión, anotemos desde ahora que tanto Eladio, Justo y Eugenio I, es decir, los obispos toledanos, antes de alcanzar la dignidad episcopal, habían formado parte del monasterio Agaliense, situado próximo a la ciudad de Toledo.

Esta tríada de hechos milagrosos representa otro tiempo -un pasado más reciente que el caso de Montano- en el que los prodigios continúan operando en el mundo sublunar, pero circunscritos a la sede de Toledo y a su más alta jerarquía. Así, el milagro involucra tanto a la figura episcopal como a su sede, la que emerge y se consolida

${ }^{23}$ ILDEF, De vir. ill., praef: “Ast ego procul ualde impar et his quos adnotatio retinet et illis quos renotatio delectauit, indignusque satis et absque substantia totius bonis operis, succesor sanctae memoriae alterius Eugenii factus in sede illa gloriosa Toletanae urbis (...), conatus sum, etsi non elegans studium uel obsequelam uoluntatis bonae, illorum admiscere memoriae gloriosae, ne incurrerem ex silentio damnum, si tam gloriosae sedis tamque gloriosorum uirorum clarescentem memoriae lucem tenebrosi nube silentii contexissem".

${ }^{24}$ ILDEF, De vir. ill., praef: "post mortem quidem sui pontificis uixit episcopus et ipse; sed tabefactus et in reprobrum uersus sensum..."

25 ILDEF, De vir. ill., praef: “...tam in reproborum sensum, tamque in languoris supereminentem...” 
como un escenario privilegiado de la intervención divina. Ahora bien, el milagro no es únicamente incorporado en el prefacio. De las trece biografías ${ }^{26}$ que integran el $D e$ viris illustribus, cuatro designan al expediente milagroso como atributo de la persona reseñada, sumando un total de siete casos.

El encargado de abrir el catálogo de viri illustres es Asturio, el primero en ser digno de un milagro gracias a "la integridad de su obispado" 27 . Ildefonso escribe que este obispo, el noveno de Toledo, mereció encontrar en el municipio complutense, por revelación divina, el sepulcro de unos mártires a cuya devoción dedicó el resto de su vida. De acuerdo con Ildefonso, había sido la mismísima divinidad la que había guiado al obispo a realizar tal hallazgo gracias a su acción virtuosa y vida ejemplar, rasgo característico del tópico del milagro ${ }^{28}$. Asimismo, como ha notado -entre otros- Jacques Fontaine, esta anécdota exhibe un claro paralelismo con la invención de cuerpos de los mártires Gervasio y Protasio realizada por Ambrosio de Milán ${ }^{29}$. De este modo, Ildefonso vincula directamente la figura episcopal, en particular la de un obispo toledano, con la gestión y difusión del culto a los santos, fenómeno que conoció un período de considerable vigor durante los siglos VI y VII.

El segundo lugar es ocupado por la noticia de Montano, donde Ildefonso nuevamente relata el milagro atribuido al obispo, mencionado previamente en el prefacio. Si bien en el contenido del milagro no se agregan nuevos elementos, Ildefonso aprovecha para ampliar la biografía y destacar su valor espiritual, elocuencia y desempeño del cargo.

En tercer lugar, Ildefonso incluye la noticia de Donato, otro personaje en el cual se reconocen indicios de milagros. No obstante, a diferencia de los demás, Donato no es obispo, sino un monje destacado por sus virtudes que había decidido, a causa de la violencia de sus tiempos y el temor ocasionado por los pueblos bárbaros, trasladarse de África a Hispania acompañado por monjes y códices literarios. Según Ildefonso, Donato fue un hombre ejemplar, considerado el primero en introducir en la península la costumbre de una regla y vinculado con la construcción y fundación del monasterio Servitano. En este caso, si bien no se detallan los milagros atribuidos, se indica que estos fueron realizados tanto durante su vida como después de su muerte ${ }^{30}$. En la mis-

${ }^{26}$ De acuerdo con la edición de Codoñer, la obra estudiada cuenta en total con trece noticias atribuidas a Ildefonso, pues no considera de autoría ildefonsiana el capítulo dedicado a Gregorio Magno. El problema radica en que esta noticia no es transmitida por la mayoría de los manuscritos. Sin embargo, en todos ellos, aparece una apostilla en el final del prefacio que menciona al papa romano y, por lo tanto, haría esperable encontrar una noticia suya inaugurando el catálogo. Según Codoñer, no obstante, se trataría de una inclusión posterior. En palabras de la editora: “Aceptamos, por consiguiente, que la redacción original del de uiris illustribus comprendía: prefacio -sin la apostilla final-, y 13 capítulos: el primero de ellos Asturius y el último Eugenius II". CODOÑER, "El «De viris illustribus» de Ildefonso", p. 504.

27 ILDEF, De vir. ill., I: "Hic et sacerdotio beatus et miraculo dignus, quia quibus iungeretur in caelo, eorum terreno reperire membra meruit in sepulchro".

28 En palabras de Ariel Guiance, este rasgo característico indica "la recurrencia directa a la Divinidad como promotora del suceso y la función intermediaria que, en el mismo, cumple el santo en cuestión". GuiAnCE, "Milagros y prodigios en la hagiografía altomedieval castellana", p.19.

${ }^{29}$ Cf. Fontaine, "El De viris illustribus de san Ildefonso de Toledo", p. 81.

${ }^{30}$ ILDEF, De vir. ill., III: "Hic et in praesenti luce subsistens et in cripta sepulchri quiescens, signis quibusdam proditur effulgere salutis, unde et monumentum eius honorabiliter colere perhibentur incolae regionis". 
ma línea, se sitúa el ejemplo de Nonnito, llamado a ocupar -por una "rápida decisión divina-" ${ }^{31}$ la silla episcopal de Gerona. De éste destaca Ildefonso su dedicación al culto del santo mártir Félix y su capacidad de operar milagros en vida y luego también desde su sepulcro. En rigor, Donato y Nonnito son los únicos ejemplos que hacen referencia a la capacidad de obrar milagros post mortem, a partir de sus reliquias.

$\mathrm{La}$ incorporación de relatos de milagros llama la atención en una obra como $\mathrm{De}$ viris illustribus, anclada en un género signado por una tradición bien definida con antecedentes visiblemente reconocidos. Si el objetivo de Ildefonso, como afirma la bibliografía, consistió en ejecutar una defensa de la ciudad de Toledo, más precisamente una exaltación de su sede episcopal, se advierte que el expediente milagroso sirvió como elemento fundamental en este cometido. En este sentido, el milagro constituyó una de las formas elegidas por Ildefonso para hacer de Toledo un locus terribilis en la medida en que adjudicó actividad taumatúrgica a sus principales representantes ${ }^{32}$. De esta manera, la sede episcopal se beneficia ella también de un legajo abultado de hombres santos, dotados de capacidad milagrosa que fortalecen su posición. Asimismo, el adjetivo "terribilis" que Ildefonso atribuye a la sede toledana remite al público directamente a las Escrituras, en particular al Antiguo Testamento, donde es utilizado en numerosísimas ocasiones como atributo de Dios (algunos ejemplos: Deut 7,21; Deut 10,17; Neh 1,5; Neh 9,32; Sal 46,3; Dn 9,4), pero también de un lugar (Gén 28,17 ) o de un ser vinculado a la divinidad (Jue 13,6). En el mismo sentido, Toledo es también calificada de gloriosa, otro adjetivo con un fuerte anclaje bíblico. Argumenta Ildefonso que la llama de ese modo "no por ser centro de atracción para innumerables hombres (...) sino porque entre los hombres temerosos de Dios es considerado lugar terrible para los injustos y para los justos digno de toda veneración"33. En rigor, la adjetivación bíblica contribuye a trazar una continuidad con los hechos milagrosos escriturísticos que avalan y habilitan la existencia de este tipo de fenómenos aun en tiempos visigodos.

Ahora bien, bajo la pluma de Ildefonso el milagro no es relegado a un pasado remoto, a diferencia de lo sostenido por el obispo Isidoro de Sevilla en las Sententiae. En esta última obra, el hispalense definió la posición de la Iglesia frente al milagro de la siguiente manera: "el motivo de que ahora la Iglesia no obra los milagros que realizaba en tiempo de los apóstoles estriba en que entonces convenía que el mundo creyese por los milagros; mas ahora, que ya cree, es preciso que brille por las buenas

31 ILDEF, De vir. ill., VIIII: “...non hominum diutina deliberatione, sed Dei per homines celeri definitione in pontificatum adscitus..."

32 Con anterioridad al De viris de Ildefonso de Toledo, otras obras elaboradas en suelo visigodo tuvieron como objetivo adosar un locus específico a la realización de milagros y prodigios. Un ejemplo lo constituyen las Vitae sanctorum patrum Emeritensium, donde se registran acontecimientos extraordinarios ocurridos en la capital lusitana entre 530- 630. En palabras de Eleonora Dell’Elicine: “...la intención de las Vitae resulta transparente: la idea era presentar a Emerita como otra Roma, como otra Jerusalém. El acontecimiento que había transformado a la vieja capital de la Lusitania en una coordenada privilegiada por el favor del Dios único era el martirio de la virgen Eulalia”. Dell'Elicine, En el Principio fue el Verbo, p. 211. Cabe aclarar que en el opúsculo del toledano, otras sedes, además de Toledo, son reconocidas también con el don del milagro, como es el caso de Gerona y su obispo Nonnito.

${ }^{33}$ ILDEF, De vir. ill., praef: “...quam non ex hominum immenso conuentu gloriosam dico, cum hanc etiam gloriosorum inlustret praesentia principum, sed ex hoc quod coram timentibus Deum iniquis atque iustus habetur locus terribilis omnique veneratione sublimis". 
obras" ${ }^{34}$. Y remataba a continuación: "todo el que, ya en posesión de la fe, exige milagros, busca por vanagloria que lo alaben"35. Isidoro reconocía la utilidad del milagro para enseñar y afianzar la doctrina en la primera hora del cristianismo ${ }^{36}$. Sin embargo, por otro lado, advertía su lado peligroso, pues permitía la emergencia -espontánea $\mathrm{y}$, por lo tanto, no controlada- de individuos hacedores de milagros ajenos a la institución eclesiástica. En ese sentido, su potencia era difícil de contener, razón por la cual Isidoro privilegiaba el poder de las obras concedido a la Iglesia, intermediaria necesaria entre los fieles y la divinidad.

Esta postura encontraba su obligado fundamento en las Sagradas Escrituras, en particular en el corpus paulino, al que Isidoro apela en su capítulo dedicado al milagro de los santos. En primer lugar, el hispalense introduce una cita literal y directa procedente de 1 Corintios con el fin de justificar su posicionamiento crítico frente a la realización de prodigios en su presente. Isidoro sostenía, citando a Pablo (1 Cor 14,22), que "las lenguas sirven de señal no para los creyentes, sino para los incrédulos" ${ }^{37}$. Es preciso notar, no obstante, que mientras Pablo se había referido allí específicamente a uno de los charismata, el don de lenguas o glosolalia, en un contexto y hacia un destinatario determinados (la comunidad de Corinto), Isidoro utiliza el versículo a los efectos de argumentar que el milagro, poco frecuente en su tiempo, constituía de hecho signo de vanagloria entre los fieles. En segundo lugar, introduce dos ejemplos de curaciones en manos de Pablo para ilustrar el desplazamiento del milagro hacia los infieles: los casos del padre de Publio y de Timoteo, inspirados respectivamente en Hch 28,8 y 1 Tim 5,23. El primero, un infiel curado de forma milagrosa, el segundo en cambio, fiel y recuperado gracias al poder medicinal. Desde la óptica isidoriana, el mensaje era bastante claro: las manifestaciones milagrosas, dirigidas especialmente a los incrédulos, no eran realizadas con frecuencia en la Iglesia del siglo VII. Aun más, advertía el hispalense que el poder de hacer milagros en la Iglesia desaparecería por completo en tiempos del Anticristo; los prodigios obrados por éste causarían confusión entre los elegidos y los inducirían al error ${ }^{38}$.

En las antípodas, la Iglesia del metropolitano de Toledo no sólo es ella misma sede de milagros, sino que son sus propios obispos los que obran tales prodigios. Por lo tanto, es la figura episcopal la que busca absorber y concentrar la potencia del fenómeno milagroso, aspecto que pasa a integrar, desde la perspectiva de Ildefonso, la lista de atributos de los viri illustres. En efecto, el hombre ilustre ildefonsiano no es ya el cristiano-escritor ponderado por Jerónimo e Isidoro en sus respectivos catálogos. Por el contrario, Ildefonso privilegia, al decir de Jacques Fontaine, la acción por encima de la pluma, la palabra hablada sobre la palabra escrita. Aún más, señala

${ }^{34}$ Isidorus Hispalensis, Sententiae [en adelante Isid. Hisp., Sent.] I, 24, 2, ed. Ismael Roca Meliá (1971). En la versión latina: "Quod nunc ecclesia non ea miracula faciat quae sub apostolis faciebat, ea causa est quia tunc oportebat mundum miraculis credere, nunc uero iam credentem oportet bonis operibus coruscare, nam ideo tunc signa fiebant exterius, ut interius fides roboraretur". Ibidem, ed. Pierre Cazier.

${ }^{35}$ IsID. HisP., Sent., I, 24, 3: "Iam in fide miracula quicumque requirit, uanam gloriam ut laudetur quaerit".

36 A pesar de esta valoración positiva del milagro en la era apostólica, Isidoro agrega: "Y, sin embargo, en los mismos apóstoles era más admirable la eficacia de las obras que el poder de los milagros. Así, también ahora en la iglesia tiene más valor vivir ejemplarmente que realizar prodigios". Isid. HisP., Sent. I, $24,1$.

37 Isid. Hisp., Sent. 1, 24, 3: "Scriptum est enim: Linguae in signum sunt non fidelibus, sed infidelibus".

38 Cf. Isid. Hisp., Sent. 1, 25, 4-5. 
el autor, el vir illustris del toledano debía ser un "hombre excelente", modelo de santidad (ascética y episcopal) y elocuencia ${ }^{39}$. Al encarar tal defensa de la sede toledana y sus representantes, Ildefonso no tiene otra opción más que hacer de la escritura un aspecto secundario o complementario de sus biografiados, pues ninguno de ellos se había destacado notablemente en aquella actividad. Por lo tanto, el protagonismo que adquiere el milagro constituye una característica fundamental de una nueva concepción de vir illustris que pone más énfasis en las virtudes y en las obras que en el ejercicio de la palabra escrita.

El uso del relato de milagros sirvió a una finalidad ${ }^{40}$ concreta: la glorificación de la ciudad y de la sede episcopal de Toledo. No obstante, también era expresión de la creciente difusión del culto a los santos y de diversas formas de vida religiosa que calaron con fuerza en la Hispania de los siglos VI y VII, en una época en la cual los relatos hagiográficos y las Vitae circulaban por dentro y fuera de los marcos eclesiásticos, al tiempo que recogían las inquietudes escatológicas de una sociedad que se preguntaba por la intervención de lo divino en lo terrenal y de lo terrenal en lo divino. En este contexto, la experiencia milagrosa no había sido prerrogativa exclusiva de la figura episcopal ni mucho menos había estado limitada únicamente a los marcos institucionales de la Iglesia.

\section{2. ¿UN ESCENARIO DE SANTOS?}

En su catálogo, Ildefonso propone un modelo de vir illustris que se alimenta de $-\mathrm{y}$ al mismo tiempo resignifica- elementos ampliamente valorados y conocidos en la época. En efecto, estas figuras hacedoras de milagros no constituían un fenómeno aislado en la Hispania visigoda de la segunda mitad del siglo VII. Por el contrario, se inscribían en un contexto de yuxtaposición de experiencias religiosas diversas. Constituye un rasgo característico de la época el protagonismo de personalidades ascéticas y eremitas vinculado al desarrollo de un monacato plural con acentuadas

${ }^{39}$ Cf. Fontaine, "El De viris illustribus de san Ildefonso de Toledo", pp. 76-77. En la misma línea, Jamie Wood sostiene: "Ildefonsus privileges appearance, virtues, monastic observance and eloquence in speaking as the defining characteristics of his illustres. Literary production is still mentioned for some of the illustres, but in at least four instances Ildefonsus states that his bishops were more eager to live exemplary lives than to write books". Wood, "Playing the fame game", p. 636.

${ }^{40}$ La finalidad de la obra ha sido objeto de discusión entre especialistas. De acuerdo con Gustav von Dzialowski, el escrito ildefonsiano habría tenido como único objetivo político la promoción de Toledo en su carácter de metrópoli. Véase, DzIALOwski, Isidor und Ildefons als Literarhistoriker. En cambio, Jacques Fontaine sostuvo, desde una perspectiva literaria, una triple finalidad: “...proseguir (...) el esfuerzo realizado desde Jerónimo hasta Isidoro; dotar a Toledo de una réplica ejemplar y original de los Diálogos gregorianos; propagar con acento más autoritario, frente a una realeza demasiado atenta a los problemas del gobierno de la iglesia, el ideal monástico y pastoral de Gregorio Magno". FonTAIne, "El De viris illustribus de san Ildefonso de Toledo", p. 95. Por su parte, Carmen Codoñer advierte el interés de Ildefonso por continuar -y completar- la obra de Isidoro con un criterio basado en la realidad de la época, es decir, recogiendo lo que en el período se valoraba como hombre santo. 
diferencias regionales ${ }^{41}$, la difusión del culto a los santos y la circulación de relatos hagiográficos ${ }^{42}$.

Uno de los ejemplos más significativos es Braulio de Zaragoza (ca. 585- 651), quien nos introduce en un escenario de santidad con la redacción de su Vita Aemilia$n i^{43}$, testimonio de la vida eremítica y monástica de la región de La Rioja. Relata la vida en solitario de Emiliano, un simple pastor de ovejas, su relación con los monjes y seguidores que acudían a su refugio, las curaciones, milagros y exorcismos; y también los prodigios realizados post mortem ${ }^{44}$. A esta importantísima obra se refiere el propio Ildefonso en la noticia destinada precisamente al obispo caesaraugustano: "escribió la vida de Millán monje, donde deja constancia de él, y hace conocidas las virtudes de aquel santo varón" ${ }^{45}$. En la misma línea, otras referencias contribuyen a consolidar el fuerte vínculo que enlazaba a la autoridad episcopal con la gestión del culto a los santos. Son los casos de los obispos Asturio, "entregado para siempre al servicio de los santos" ${ }^{46}$, Nonnito y Eugenio II, consagrado el primero "al servicio del sepulcro del santo mártir Félix" y el segundo "al culto de los sepulcros de los mártires"48.

En Hispania, los siglos VI y VII conforman un período de creciente proliferación de monasterios y eremitorios extendidos por diversas zonas del reino visigodo, especialmente en la región del Bierzo ${ }^{49}$ ubicada entre Galicia y la cuenca del Duero, centro de la actividad de dos de las personalidades más significativas de la época:

${ }^{41}$ Uno de los ejemplos más emblemáticos de la diversidad del fenómeno monástico en la Hispania visigoda corresponde a la organización en forma monástica de comunidades campesinas en el Noroeste peninsular. Para un estudio exhaustivo del caso, véase: DíAz, "Comunidades monásticas y comunidades campesinas en la España visigoda", pp. 189-196; Ibidem, "Regula Communis: monastic space and social context", pp.117-135.

42 La bibliografía en torno de la hagiografía medieval es vastísima. Mencionamos algunos títulos orientativos, en particular para el caso hispánico: Castellanos, La hagiografía visigoda: dominio social y proyección cultural; MARTín Viso, "The memory of holy men”, pp. 165-190; VeLÁzQuez, La literatura hagiográfica; una mirada más general en WARD, Miracles and the medieval mind. Asimismo, son fundamentales los trabajos precursores de Peter Brown acerca del hombre santo en la Antigüedad tardía (Véase nota 1).

${ }^{43}$ Cf. Castellanos, Poder social, aristocracias y hombre santo en la Hispania visigoda.

44 A propósito de Braulio de Zaragoza, Eleonora Dell'Elicine señaló: "Braulio de hecho modificó tres puntos importantes: en primer lugar, los milagros que anotó (...) pertenecieron a su pasado más reciente, un pasado del que aún existían testigos vivos. En segundo lugar, estos prodigios fueron realizados en el alto valle del Ebro, dentro de la jurisdicción de una corona visigoda todavía arriana. (...) Finalmente y para terminar, el relato incorporó en grados diferenciados a otros actores sociales involucrados en el despliegue de tan extraordinarios sucesos”. Dell'Elicine, En el Principio fue el Verbo, pp. 228-229.

${ }^{45}$ ILDEF, De vir. ill., XI: "Scripsit uitam Aemiliani cuiusdam monachi, qui et memoriam huius et uirtutem illius sancti uiri suo tenore commendat pariter et inlustrat”.

46 Ibidem, I: "...seruitute simul et adsiduitate sanctis innexus..."

${ }^{47}$ Ibidem, VIIII: “...adhaerens instanter obsequiis sepulchri sancti Felicis martyris”.

48 Ibidem, XIII: “...illic martyrum sepulchris inhaesit...”,

49 "El Bierzo was an area that had a fully consolidated Christian landscape, with churches, oratories and monasteries, which in no way should be interpreted as if Christianity was the factor that structured the whole landscape. In this context, there were different traditions that competed to earn social prestige and thus, become hegemonic. The greatest protector of one of these was Valerius, who defended a model based on asceticism, but anchored in the tradition of the fathers of the desert, with a strong character charismatic, strongly based on individual charisma and in the construction of a "textual community" that served as a basis for this microchristendom. However, these traditions conflicted with each other and used various means to earn this prestige". En MARTíN VISO, "The memory of holy men”, pp. 174-175. 
Fructuoso de Braga, fundador de los monasterios de Compludo y de San Pedro de Montes («Rufianense»), y Valerio del Bierzo. En rigor, las obras de este último, a pesar de su carácter autobiográfico, resultan de enorme importancia para el estudio de las prácticas ascéticas vinculadas al fenómeno eremítico en la península ${ }^{50}$.

Instalados en un refugio rocoso en frente de la iglesia de san Félix, Valerio y su discípulo fueron centro de atracción de numerosos fieles que llegaban a la zona ofreciendo ayuda, bienes y sumisión. Estos episodios recurrentes llevaron a sucesivas confrontaciones con el presbítero Flaíno, quien, al advertir la pérdida de feligreses, rentas y donaciones, logró finalmente el desplazamiento del eremita. Cabe señalar que aquel personaje aparece en la obra de Valerio como un hombre "lujurioso, ocupado en toda clase de liviandades, que instigado por el demonio habría empezado a difamarle y urdir contra él trampas y actos malévolos" ${ }^{51}$. Luego de su estancia en la finca de Ebronanto, alojado en una celda próxima al altar de una iglesia privada $-\mathrm{y}$ llevado allí probablemente por su capacidad de atraer numerosos fieles- se instala finalmente en el Rufianense, donde se gana la enemistad del abad y de los monjes gracias a su desprecio manifiesto por la jerarquía y la desobediencia a la disciplina monástica $^{52}$. Este brevísimo recorrido por su itinerario pone de manifiesto la crítica explícita a las autoridades eclesiásticas y monásticas, y privilegia en cambio un vínculo directo y sin mediación con la divinidad.

Ahora bien, los testimonios que nos proporcionan las personalidades de la época resultan más bien escasos y no nos permiten lógicamente asir el fenómeno eremítico en su total extensión y complejidad. No obstante, algunos avances se han registrado recientemente en el campo de las investigaciones arqueológicas en España gracias a la renovación de esta disciplina y al incremento de excavaciones en la península ${ }^{53}$ que permitieron vislumbrar un panorama considerablemente más complejo de la organización social y de la jerarquización espacial. Los estudios sobre eremitorios e iglesias rupestres se intensificaron especialmente en la zona del alto valle del Ebro, donde se observaron espacios habituales en forma de complejos o colonias identificadas con formas semieremíticas ${ }^{54}$. Asimismo, la fundación de edificios de culto de distinta índole se extendió a los alrededores de Toledo, donde se ubicaron establecimientos monásticos -como el Agaliense-, centros eclesiásticos locales y áreas cementeriales. Asimismo, durante el siglo VII la capital visigoda incorporó el culto a Leocadia, desde entonces convertida en santa protectora de la ciudad. La basílica que se consagra a su veneración fue fundada por el rey Sisebuto en 618 y funcionó como una de las principales sedes de los concilios generales convocados en ese siglo. La adopción de

${ }^{50}$ Cf. DíAz, "El eremitismo en la Hispania visigoda”, pp. 59-83.

51 Ibidem, p. 65.

52 Para un estudio acerca del eremitismo en general y de la trayectoria de Valerio del Bierzo en particular, véase: CoRullón, "El eremitismo en las épocas visigoda y altomedieval", pp. 48- 62.

53 Según R. Collins: "Algunas investigaciones arqueológicas llevadas a cabo en época reciente han hecho que en muchos lugares de la península Ibérica apareciera un número cada vez mayor de cuevas que han sido identificadas como iglesias y celdas de ermitaños o monjes de la época visigoda. La distribución de estos lugares depende de las características geológicas requeridas para la existencia de cuevas habitables, pero han sido encontradas en diversas ubicaciones diferentes y no cabe duda de que el número de emplazamientos descubiertos seguirá aumentando”. Collins, La España visigoda, p. 214.

54 Cf. Monreal Jimeno, “Centros eremíticos y semieremíticos en el valle del Ebro”, p. 50. 
este culto, que encontró en Ildefonso a uno de sus principales promotores, se enlaza directamente con la afirmación de Toledo como centro político-religioso del reino ${ }^{55}$.

Al lado de la documentación hagiográfica y arqueológica, una tercera fuente nos permite dar cuenta de la circulación de monjes y eremitas, y de la propagación de formas de vida religiosa que lograban sortear los límites institucionales. Ya en el año 633, el concilio IV de Toledo había dispuesto dos cánones que pretendían legislar sobre este tipo de prácticas. El primero de ellos, el canon LII, se aplicaba a los monjes que decidían dejar el monasterio al que pertenecían, regresar a la vida secular e incluso contraer matrimonio. A éstos se les ordenaba el regreso inmediato al establecimiento y la penitencia ${ }^{56}$. En la misma línea, el canon LIII, referido a los religiosos errabundos, disponía:

Al abuso de los religiosos de cada territorio que no se cuentan entre los clérigos ni entre los monjes, así como el de aquellos que andan vagando por diversos lugares, pondrá coto el obispo en cuya jurisdicción residen, destinándolos al clero o a los monasterios... ${ }^{57}$

Una década más tarde, en 646, un nuevo concilio convocado por el rey Chindasvinto advertía nuevas e insistentes medidas al respecto:

Al establecer medidas severas, mandamos excluir con justo criterio a aquellos a los que el deseo de una vida santa retiene apartados en sus propias celdas (...) Pero aquellos otros que fueron impulsados a tal estado de vida por la pereza, no por el conocimiento de la verdad, y a los que no prestigia una vida digna, sino lo que aun es peor, los afea la ignorancia y los deshonra unas costumbres detestables, decretamos que sean arrojados de aquellas celdas y de los lugares en los que habitan como vagabundos o permanecen recluidos, y que desean destinados a vivir en monasterios por los obispos y los rectores de los monasterios a cuya congregación pertenecieron o en cuyas cercanías habitan... ${ }^{58}$

En este contexto de proliferación de loca sacra y de figuras itinerantes, el hecho milagroso aparece en la obra de Ildefonso circunscrito a un lugar específico, la sede episcopal de Toledo, y en manos de la más alta jerarquía eclesiástica. De este modo, no solamente había allí una intención de exaltar la sede toledana por encima de las demás, sino también la de jerarquizar un modelo de hombre santo que desde la institución hiciera frente a una realidad más compleja y diversa en la cual coexistían

${ }^{55}$ Cf. Martin, La géographie du pouvoir, p. 225 y ss; Olmo Enciso, "Ciudad y Estado en época visigoda", pp. 87- 112 .

56 "Nonnulli monachorum egredeuntes a monasterio non solum ad saeculum reuertuntur sed etiam et uxores accipiunt. Hi igitur reuocati in eodem monasterio a quo exierant, paenitentiae deputentur ibique defleant crimina sua unde decesserunt”. Tol. IV, c. LII, ed. MarTínez Diez, RodríGuez, La colección canónica hispana, pp. 231-232.

${ }^{57}$ Tol. IV, c. LIII, p. 209. En adelante, las citas en español corresponden a la edición de VIVES, Concilios visigodos e hispanoamericanos. En la versión latina: "Religiosi propriae regionis qui nec inter clericos nec inter monachos habentur, siue ii qui per diuersa loca uagi feruntur, ab episcopis in quorum conuentu commanere noscuntur licentia eorum coerceatur, in clero aut in monasteriis deputati, praeter hii qui ab episcopo suo aut propter aetatem aut propter languorem fuerint absoluti”. MARTínEz DiEZ, RodríGUEZ, La colección canónica hispana, p. 232.

${ }^{58}$ Tol. VII, c. V, p. 255. 
distintas formas de definir el vínculo con la divinidad y, por lo tanto, de escapar exitosamente al control y a la mediación de la Iglesia. Cabe destacar, sin embargo, que la diversidad de prácticas y conductas también se manifiesta en el interior del clero visigodo, tal como se observa en la documentación conciliar, en la cual se exhorta a sus miembros a evitar las formas inadecuadas de acceso al obispado y los comportamientos contrarios a la piedad y a la norma cristiana. En este sentido, los hombres ilustres de Toledo representan también modelos de vida y conducta para aquellos que, luego de su ordenación, habían descuidado sus prácticas y formas de vida.

En síntesis, el vir illustris de Ildefonso se halla encuadrado en el monasterio o preferentemente en la sede episcopal. La mayoría de las personalidades reseñadas ejercen el cargo de obispo con la sola excepción del monje Donato. Además, buen número de las noticias nos informan que estos hombres ilustres antes de alcanzar la dignidad episcopal formaron parte de comunidades monásticas, tal como demuestran los casos de Eladio, Justo, los dos Eugenios y sin ir más lejos el propio Ildefonso, monje y abad del monasterio de Agali ${ }^{59}$. De esta manera, los obispos toledanos, especialmente aquellos formados en el establecimiento agaliense, funcionan como auténticos modelos de comportamiento y por extensión Toledo se consolida como centro de poder y santidad.

\section{LA CAPITALIZACIÓN EPISCOPAL DEL MILAGRO}

\subsection{PRESENTE}

En trabajos recientes, Santiago Castellanos definió a la Vita Aemiliani de Braulio de Zaragoza como ejemplo paradigmático del proceso de capitalización episcopal del culto a los santos. De acuerdo con el autor, los hombres santos ejercían la mediación entre la comunidad y la divinidad, y otorgaban unanimitas al grupo. Constituían, de este modo, "un elemento de cohesión y de control social para quienes [conseguían] capitalizar los procesos" ${ }^{\prime \prime 0}$. En su mayoría, estos procesos se concentraron en manos de la aristocracia episcopal, encargada del culto y de su difusión ${ }^{61}$. El análisis de fuentes hagiográficas ofrecido por Castellanos demuestra, no obstante, la conflictiva relación entablada entre el hombre santo y la autoridad especialmente durante su período vital. Los grupos dirigentes interesados en controlar los efectos del santo en la comunidad debieron ocasionalmente enfrentarse con estas figuras, lo cual dio

${ }^{59}$ La conexión entre Agali y Toledo fue sin duda de enorme importancia. Numerosos obispos de Toledo fueron educados y formados en aquel centro monástico, motivo por el cual se llegó a hablar de "auténticos grupos de presión clericales" procedentes de Agali en el control de la sede toledana. Cf. GARCÍA MorENO, "Los monjes y monasterios", p. 191. Del mismo autor, véase también: "Disenso religioso y hegemonía política”, pp. 47-63.

60 Castellanos, "Conflictos entre la autoridad y el hombre santo", p. 78.

${ }^{61}$ En la misma línea, Iñaki Martín Viso señaló la importancia de la capitalización del culto de los santos vinculada con la fundación de nuevas sedes episcopales: "Determinados santos se convirtieron en los patrones del poder episcopal, mediante un mecanismo bien conocido en el caso de san Millán con Braulio de Zaragoza. Se precisaban personajes con trascendencia local que justificaran ideológicamente la elección de una sede, como santos Emeterio y Celedonio en Calahorra y, quizás, san Felices en Oca”. MARTín Viso, "Organización episcopal y poder", p. 164. 
lugar a conflictos puntuales que involucraron a la autoridad tanto real como episcopal. Dentro del primer grupo, el autor sitúa las disputas entre el rey Leovigildo y el obispo emeritense Masona ${ }^{62}$ hacia finales del siglo VI, y entre Fructuoso de Braga y Chindasvinto, rey visigodo entre los años 642-653. Dentro del segundo, en cambio, los conflictos citados implicaron a Emiliano y Didimio, y a Valerio del Bierzo e Isidoro de Astorga.

Ahora bien, si volvemos al caso de Ildefonso, podemos advertir en su De viris illustribus la intención de capitalizar la capacidad de operar milagros en favor de determinados personajes, en su mayoría obispos y toledanos, colocados en la historia de la sede episcopal como hacedores de prodigios dotados de una conducta virtuosa. En otras palabras, estas anécdotas que involucran un hecho sobrenatural ocurrido en Toledo pasan a engrosar el pasado de la sede episcopal desde donde proyectan su fuerza hacia el presente y le otorgan prestigio y autoridad.

Como observamos en un primer momento, el conflicto no se halla ausente del opúsculo ildefonsiano: tres de las cuatro anécdotas de milagros compendiadas en el prefacio representan episodios de insubordinación y disputa en el interior de la sede episcopal. En los tres casos, Ildefonso narra la confrontación entre el metropolitano de Toledo -Eladio, Justo, Eugenio I- y un subordinado -Justo, Geroncio, Lucidioquien, en dos de los ejemplos citados, cuenta con el apoyo de otro sector ajeno a la Iglesia. Relata Ildefonso que Geroncio contó con el apoyo del princeps, mientras que Lucidio obtuvo el sostén de sus amicitiae saeculari. En los tres casos, además, el milagro se hace presente en la contienda a favor del metropolitano de Toledo y, como consecuencia, quienes protagonizan los actos de desobediencia sufren el castigo divino.

En otras palabras, se advierte una implementación política de la potencia del milagro a los efectos de demostrar, en primer lugar, que la sede de Toledo es un locus de intervención divina y, en segundo lugar, que el favor divino es otorgado precisamente a sus máximos representantes. Ahora bien, éstos no se destacan únicamente por ocupar a su tiempo la silla episcopal de Toledo. Además, Eladio, Justo y Eugenio I comparten un pasado en común: todos ellos habían formado parte del monasterio de Agali, establecimiento situado en las cercanías de la ciudad, con el cual Ildefonso también se encontraba íntimamente relacionado. En este sentido, en las sucesivas confrontaciones entre el metropolitano y el clero catedralicio se advierte la disputa por el control tanto del patrimonio eclesiástico como de la propia sede toledana en manos de los hombres procedentes de Agali. Por lo tanto, la sede episcopal se erige como un verdadero centro de poder en el que se manifiesta la conexión, no exenta de conflicto y tensión, entre poder político y poder episcopal. En efecto, como se advierte a partir de los episodios relatados por Ildefonso, en el control de la sede metropolitana se imbrican a su vez los intereses de grupos aristocráticos fuertemente vinculados con la jerarquía clerical.

62 “...la idea de Leovigildo de terminar con Masona si no podía controlarlo (...) hubiera supuesto para el monarca no sólo acceder a amplios recursos materiales, sino también controlar el patronatus de Masona hacia la comunidad, que adquiría carta de caelestis por la especial mediación y vínculo personal del obispo emeritense con la mártir Eulalia”. Ibidem, p. 80. 2016, vol. 39 49-72 
En el primer relato, el princeps que, de acuerdo con Ildefonso, ofreció su apoyo a la insubordinación de Geroncio fue el rey Sisenando ${ }^{63}$, quien había asumido el trono visigodo en 631 luego de liderar una revuelta nobiliaria que contó con el apoyo del ejército del franco Dagoberto, rey de Neustria, y finalizó con el largo reinado de Suintila (621-631). Ildefonso no proporciona detalles del enfrentamiento y se limita a mencionar únicamente que el sacerdote había utilizado el sostén real para mostrar su desprecio y hostilidad al metropolitano (contemptum aduersitatemque). A pesar de su breve extensión, este episodio deja entrever no solo la capacidad del rey de intervenir exitosamente en los asuntos eclesiásticos sino también de enfrentarse, aunque indirectamente, al mismísimo metropolitano de Toledo. Con la misma brevedad, Ildefonso cuenta el caso de Lucidio, un diácono que por medio de la violencia y el respaldo de sus amistades mundanas logró ser ordenado presbítero y obtener quaedam praedia ${ }^{64}$. A partir de esta concatenación de hechos similares, Ildefonso revela dos tópicos constantemente evocados en los concilios visigodos del siglo VII. Por un lado, en las actas conciliares se observan numerosos cánones destinados a reglamentar la administración de los bienes de la Iglesia, a condenar la usurpación y la avaricia, y a denunciar reiterados conflictos en torno de la apropiación indebida de tierras ${ }^{65}$. Por otro lado, otra serie de cánones insistió en la necesidad de acabar con la perniciosa costumbre de ordenar clérigos no aptos desde el punto de vista de la norma canónica. En este punto, la preocupación principal de los obispos visigodos fue la simonía ${ }^{66}$, aunque otras formas de acceso a la dignidad eclesiástica también se condenaron como la necesidad o el miedo a los peligros ${ }^{67}$.

A diferencia de los casos de Lucidio y Geroncio, en el episodio del diácono Justo, Ildefonso no explicita la intervención de otros agentes. No obstante, como destaca Carmen Codoñer, en este episodio también se advierte el conflicto entre facciones aristocráticas, anclado en los distintos sectores de la Iglesia. De acuerdo con la autora, Justo habría sido favorable a un sector intransigente de la nobleza goda enfrentado con aquellos que, como el obispo Eladio, encontraban su apoyo en la aristocracia hispano-romana. Desde esta perspectiva, Eladio, inclinado a sostener la línea conti-

63 Cf. García Moreno, "Disenso religioso y hegemonía política", p. 56; Thompson, Los godos en España, p. 207.

${ }^{64}$ ILDEF, De vir. ill., praef: “Adhuc etiam successori in locum eius Eugenio priori Lucidius diaconus suus, cum innexus amicitiae saeculari uiolenter honorem presbyterii et quaedam praedia extorsisset”.

65 Cf. Tol. IX.

${ }^{66}$ Algunos ejemplos: Tol. IV, c. XIX, p. 199: “...mientras unos buscan el episcopado mediante intrigas, otros lo consiguen ofreciendo recompensas, y así hasta algunos, complicados en actos criminales o ya alistados en el ejército, llegan al honor del sumo y sagrado orden”; Tol. VI, c. IV, p. 237: “...cualquiera que imitando a Simón incurriere también en la herejía simoníaca, de modo que alcance los grados de las órdenes eclesiásticas, no por la pureza de sus costumbres, sino que los consiga con regalos y dádivas, y los tome mediante el soborno (...) no se le permita en modo alguno alcanzar las cumbres de las sagradas órdenes. Y si las hubiere ya alcanzado prívesele de la comunión (...) sea condenado a la pérdida de todos sus bienes..."; Tol. VIII, c. III, p. 278: "a cualquiera que de ahora en adelante se le descubriere algún premio por recibir la dignidad episcopal, sepa que está condenado con el oprobio del anatema. (...) Y aquellos que hubieren recibido por estos motivos los regalos, si fueren clérigos serán castigados por la pérdida de su grado..."

${ }^{67}$ Tol. VIII, c. VII, p. 280. 
nuada por los reyes Recaredo, Sisebuto y Suintila, habría representado un elemento opositor a la política del monarca vigente ${ }^{68}$.

Indudablemente, estos episodios que hacen de la rivalidad intraeclesiástica el centro de la escena constituyen referencias -evidentes para los ojos de la época- al contexto más inmediato de Ildefonso, decidido a enviar a su audiencia un mensaje determinado. Con seguridad, el público al que se dirige Ildefonso conoce bien la situación interna de la Iglesia visigoda y particularmente de la sede toledana. Aún más, se trata de un público familiarizado con las Escrituras y los personajes descritos en la obra, un público al que los relatos de milagros sin duda atraen y convocan.

En la segunda mitad del siglo VII Toledo se había transformado en el principal centro administrativo y eclesiástico del reino visigodo ${ }^{69}$. En rigor, ya desde principios de siglo, como señala Gisela Ripoll, la ciudad fue adquiriendo una mayor notoriedad y distinción en el ámbito político-religioso y $\operatorname{militar}^{70}$. Un factor decisivo fue el establecimiento de la capital del reino en Toledo considerada como tal desde tiempos del rey Atanagildo ${ }^{71}$ (555-567), aunque, como indica la misma autora, aparece por primera vez así denominada en las actas del tercer concilio general en 589. Sin embargo, esta encumbrada posición no fue alcanzada sin conflicto. Hasta mediados del siglo VI la primera ciudad de la provincia de Carthaginiensis, circunscripción administrativa de la cual formaba parte Toledo, había sido Cartagena (Carthago Spartaria), ocupada por los bizantinos en 552 y recuperada recientemente en el año $624^{72}$. Mientras tanto,

${ }^{68}$ Según la autora, Eladio habría sido "un factor determinante del retraso en la convocatoria del IV concilio de Toledo. Partidario claro de Sisebuto y Suintila, el reconocer la validez de la usurpación de Sisenando supone para él la renuncia a sus principios, la ruptura con un planteamiento mantenido a lo largo de muchos años". CODOÑER, "El «De viris illustribus» de Ildefonso", p. 536.

69 "The royal city of Toledo, capital of the kingdom, was the centre of cultural activity. Many sons and daughters of the Gothic nobility came there to receive an education. The monastery of Agali at the gates of the city educated monks and clerics, but also lay people. Even at court, certain educated princes followed the tradition founded by king Sisebut, the friend of Isidore, exercising a sort of patronage and frequenting the archbishops of Toledo, of whom several left grammatical, poetical, historical and theological works". FonTAIne, "Education and learning", p. 752.

${ }^{70}$ Cf. RiPOLL, "Changes in the topography of power", pp. 123-148. La importancia ejercida por Toledo ya desde el siglo VI ha sido destacada en distintos trabajos recientes. En palabras de A. Chavarría: "El territorio de la Meseta formaba parte de varias circunscripciones administrativas: la Gallaecia, la Tarraconensis, la Carthaginensis y la Lusitania. A inicios del siglo VI la organización de esta zona fue modificada con la creación de la Carpetania vel Celtiberia, reorganización vinculada a la creciente importancia de Toledo en época visigoda y la extensión de la influencia de esta ciudad hacia esta zona”. ChavArRía ArnaU, “Castillos en el aire?", p. 134.

71 "The city of Toletum had already acquired a certain preeminence in the time of Theudis, although it was more securely considered as the capital-with all the pertinent administrative, aristocratic and royal machinery - as from 568, under Athanagild, who died in the same year, and this role as capital was fully reasserted during Leovigild's reign". RIPOLL, "Changes in the topography of power", p. 136.

72 “A principios del siglo VI hizo su aparición una sedicente provincia de Celtiberia o Carpetania, con Toledo como metrópoli; luego, otra parte de la provincia y la propia capital, Cartagena, cayeron dentro del ámbito de los dominios bizantinos en España. El problema se expuso con todos sus pormenores en el reinado de Gundemaro. Aquí bastará recordar que un decreto de este monarca del año 610 aclaró la situación declarando que no existía más provincia que la Cartaginense y que Toledo era su metrópoli”. ORLANDIS, Época visigoda, p. 217. En la misma línea, Roger Collins sostiene: “durante un sínodo celebrado en la capital en 610 , se produjo la transferencia del obispado metropolitano de la provincia de la Cartaginense, que aún estaba en manos bizantinas, a Toledo. Esto hizo que la hasta entonces casi desconocida iglesia de Toledo se convirtiera en la sede del primado de la Cartaginense, formalizando así la estrecha relación que se desarrollaría 
en la primera mitad del siglo VI Toledo se convirtió en sede metropolitana y lugar de la corte del rey. En este sentido, se advierte en la obra de Ildefonso un pronunciado interés en destacar la antigüedad de Toledo en tanto sede metropolitana, al indicar con cierto detalle los períodos durante los cuales sus viri illustres habían ocupado la silla episcopal, ya sea señalando la posición dentro de una lista sucesoria de obispos, o bien indicando su antecesor o los reinados durante los cuales habían transcurrido los correspondientes pontificados ${ }^{73}$. Por ejemplo, Asturio es catalogado como "sacerdos nonus", mientras que a Montano le atribuye el haber ocupado "después de Celso la silla episcopal de la ciudad toledana, sede principal de la provincia cartaginense"

En este contexto, la necesidad de dotar a Toledo de un pasado glorioso tenía como objetivo fortalecer su status y fundamentar su primacía sobre otras ciudades y sedes tanto en el interior de la provincia como en el de la Hispania en general. Desde esta perspectiva, por tanto, Toledo debía ser destacada frente a ciudades cuya historia podía situarlas en una posición de mayor ventaja, pero también frente a ciudades como Sevilla, vinculada esta última a personajes de la talla de Leandro e Isidoro, hombres de iglesia destacados por sus importantes obras así como por su desempeño en el cargo episcopal de Hispalis.

\subsection{FUTURO}

En síntesis, el milagro constituyó un elemento fundamental tanto en la construcción de un pasado glorioso para Toledo como en la codificación de los conflictos políticoreligiosos que acuciaban al reino y se manifestaban en el presente de la sede episcopal. No obstante, en un tercer nivel el milagro también hacía posible un discurso sobre las cosas futuras, vinculado a la espera escatológica que desde antiguo había mantenido en vilo a las jerarquías eclesiásticas del reino.

Convertir Toledo en un centro de milagros conllevaba implicaciones temporales y espaciales. En primer lugar, suponía afirmar que las intervenciones de Dios en el plano terrestre no habían llegado a su fin. La creencia de que los milagros desaparecerían de la faz de la tierra en un tiempo próximo al fin de los tiempos había sido ya transmitida en Hispania por Isidoro de Sevilla. En este sentido, Ildefonso apuntaba indirectamente a una prolongación de los plazos de la espera escatológica, pues dejaba entrever que Dios seguía actuando en aquella parte del mundo. En segundo lugar, estos prodigios eran realizados en tierras visigodas. Esto significaba adjudicar a la antigua provincia romana un papel principal dentro de la cristiandad en tanto que escenario receptor de la acción divina. Aún más, la voluntad de Dios en la tierra se manifestaba por intermedio de la Iglesia, en especial a través de la sede toledana, y

entre los obispos de la capital y los reyes a los que éstos servían”. Collins, La España visigoda, p. 73. Otros especialistas, sin embargo, han cuestionado la autenticidad del decreto de Gundemaro. Para este último punto, véase: González BlanCo, "El decreto de Gundemaro y la historia del siglo VII", pp. 159-170.

73 A modo de ejemplo, citamos los casos de Aurasio quien "vixit in sacerdotio temporibus Vuitterici, Gundemari et exordiis Sisebuti regum, annis ferme duodecim" (ILDEF, De vir. ill., IV), de Eladio "Temporibus Sisebuti, Suinthilanis et exordiis Sisenandi regum beatus habitus fuit" (ILDEF, De vir. ill.,VI) y de Eugenio II, "Item Eugenius alter post Eugenium pontifex subrogatur" (ILDEF, De vir. ill, XIII).

${ }^{74}$ ILDEF, De vir. ill., II, 16: "Montanus post Celsum primae sedis prouinciae Carthaginis Toletanae urbis cathedram tenuit". 
eran sus representantes, los obispos, aquellos que habían sido privilegiados con el poder de obrar milagros. Este aspecto es visible especialmente en las cuatro anécdotas del prefacio, donde Ildefonso relata la intervención divina favorable al metropolitano de turno.

Desde esta perspectiva, los hechos milagrosos acaecidos en Toledo constituían verdaderos signos del favor divino que afectaban no solamente a la ciudad regia sino al reino visigodo en su totalidad. En efecto, eran señales consideradas indicios de salvación en estrecho vínculo con unas pautas de conducta austeras y rigurosas. Sobre este punto Ildefonso se extendió en otro breve opúsculo elaborado también durante su pontificado en Toledo que conocemos bajo el título de De itinere deserti. Interesado en impartir las instrucciones que el hombre cristiano ya bautizado debía seguir a fin de alcanzar la vida futura, Ildefonso buscó transmitir un modelo de comportamiento a imitar basado en el riguroso ascetismo de los santos. Asimismo, ponderaba la renuncia a las riquezas materiales, a los vicios y placeres carnales, y proponía en cambio una vida ascética, austera y virtuosa. Desde esta perspectiva, la santidad no podía jamás ser alcanzada en virtud del cargo, la riqueza o el linaje, sino principalmente a partir de la adopción de rigurosas pautas de conducta. En este sentido, el milagro era concedido al hombre santo gracias a su vida ejemplar y en virtud de esta vida ejemplar el hombre se sabía en el camino correcto para alcanzar la salvación.

\section{CONCLUSIONES}

Poco más de dos décadas separan a Ildefonso de Toledo de Isidoro de Sevilla ( $c a$. 556- 636). Sin embargo, un período tan corto de tiempo no impidió que se elaboraran rápidamente nuevas actitudes frente al hecho milagroso. En un contexto en el que se reivindican la caridad y la austeridad como pilares del modelo de santidad, el fenómeno del milagro deja de ser cuestión de incrédulos e infieles para volverse, según Ildefonso, prerrogativa de obispos y eclesiásticos.

A lo largo de estas páginas hemos advertido la utilización del milagro en función de un objetivo concreto: dotar a Toledo de un pasado glorioso que permitiera exaltar su sede episcopal y a sus principales representantes. No obstante, el hecho de que el milagro haya sido un componente fundamental de esta construcción nos remite a un contexto particular en el cual distintas experiencias religiosas abundan y se multiplican a lo largo y a lo ancho del reino visigodo. Desde los tiempos de Isidoro (e incluso también antes del concilio IV de Toledo), la Iglesia y su más alta jerarquía se habían mostrado preocupadas por la amenaza que representaban ciertas formas heterogéneas de concebir la perfección espiritual y la relación de los fieles con la divinidad.

El recurso a lo milagroso permite así operar simultáneamente en distintos niveles: al mismo tiempo que forma parte de un pasado (reciente o no), habilita en función de su continua irrupción en el mundo sublunar un discurso sobre el presente que afecta, a su vez, la percepción de las realidades futuras. En este sentido, los relatos de milagros constituyen verdaderos codificadores de la espera escatológica, pues al ser considerados indicios de la intervención divina en la tierra, prolongan la llegada de los últimos tiempos. Desde esta perspectiva, los portentos realizados por los viri illustres 2016, vol. 39 49-72 
de Ildefonso le otorgan a la ciudad de Toledo un lugar privilegiado dentro del plan divino que contribuye a su elevación y distinción. De este modo, el obispo toledano reivindica el protagonismo de la capital visigoda frente a otras ciudades, pero también frente a otras sedes cristianas y demuestra que en Occidente (y particularmente en Hispania) los signos divinos continúan manifestándose.

En consecuencia, el milagro es un don carismático concedido al hombre por la gracia divina, pero concentrado en la figura episcopal toledana. En efecto, con sus breves noticias de hombres ilustres, Ildefonso deja entrever que no todos los fieles pueden ser dignos de tal poder. Únicamente aquellos ordenados que siguieran unas pautas de conducta de riguroso ascetismo, cultivo de virtudes y rechazo de placeres mundanos, como ejemplifica su catálogo de hombres santos, pueden merecer un don de tal magnitud. En definitiva, definir las condiciones bajo las cuales se habían producido - y se seguían produciendo- tales prodigios, significaba también controlar su potencial semiótico.

\section{FUENTES}

Ildefonso de Toledo, De viris illustribus, Codoñer Merino Carmen (ed.), El De viris illustribus de Ildefonso de Toledo. Estudio y edición crítica, Salamanca: Universidad de Salamanca, 1972; CoDoÑER Merino Carmen, "El «De viris illustribus» de Ildefonso de Toledo", en Carmen Codoñer, Valeriano Yarza Urquiola (eds.), Ildefonsi Toletani episcopi Opera, CCSL 114, Turnhout, 2007.

Isidoro de Sevilla, Sententiae, Cazier Pierre (ed.), Isidorus Hispalensis. Sententiae, Turnhout: Brepols, 1998; Roca Meliá, Ismael (ed.), "Los tres libros de las Sentencias de san Isidoro, obispo de Sevilla”, en Ismael Roca Meliá, J. Campos Ruiz, Santos Padres españoles II, Madrid, BAC, 1971.

Concilios visigodos, Vives José (ed.), Concilios visigodos e hispanoamericanos, Madrid: CSIC, 1963; MarTínez Diez Gonzalo, RodríGuez Félix (eds.), La colección canónica hispana. V. Concilios hispanos, segunda parte, Madrid: CSIC, 1992.

\section{BIBLIOGRAFÍA}

Blackburn, Barry Lee, "The miracles of Jesus”, en Graham Twelftree (ed.), The Cambridge companion to miracles, Cambridge: Cambridge University Press, 2011, pp. 113-130.

Brown, Peter, "The rise and function of the Holy Man in Late Antiquity", The Journal of Roman Studies, 61 (1971), pp. 80-101.

Brown, Peter, The cult of the saints. Its rise and function in Latin Christianity, Chicago: Chicago University Press, 1981.

Brown, Peter, Society and the holy in Late Antiquity, California: University of California Press, 1982.

Brown, Peter, Authority and the sacred in Late Antiquity, Cambridge: Cambridge University Press, 1995. 
Castellanos, Santiago, "Conflictos entre la autoridad y el hombre santo. Hacia el control oficial del patronatus caelestis en la Hispania visigoda", BROCAR, 20 (1996), pp. 77-89.

Castellanos, Santiago, La hagiografía visigoda: dominio social y proyección cultural, Logroño: Fundación San Millán de la Cogolla, 2004.

Castellanos, Santiago, Poder social, aristocracias y hombre santo en la Hispania Visigoda. La Vita Aemiliani de Braulio de Zaragoza, La Rioja: Universidad de La Rioja, 2011.

Chavarría Arnau, Alexandra, “¿Castillos en el aire? Paradigmas interpretativos «de moda» en la arqueología medieval española”, en De Mahoma a Carlomagno: los primeros tiempos, siglos VII-IX: XXXIX Semana de Estudios Medievales, Estella, 17-20 julio 2012, Pamplona, 2013, pp. 131-166.

Codoñer Merino, Carmen, "Los De viris illustribus en la Hispania visigótica. Entre la biografía y la hagiografía”, en Vitalino Valcárcel Martínez (coord.), Las biografías griega y latina como género literario: de la Antigüedad al Renacimiento: algunas calas, Bilbao: Universidad del País Vasco, 2009, pp. 239- 255.

Collins, Roger, La España visigoda 409-711, Barcelona: Crítica, 2005.

Corullón, Isabel, "El eremitismo en las épocas visigoda y altomedieval a través de las fuentes leonesas I", Tierras de León. Revista de la Diputación Provincial, 64-26 (1986), pp. 48-62.

Dell'Elicine, Eleonora, En el principio fue el Verbo. Politicas del signo y estrategias del poder eclesiástico en el reino visigodo de Toledo (589- 711), Cádiz: UCA, 2013.

DíAz, Pablo de la Cruz, "Comunidades monásticas y comunidades campesinas en la España visigoda”, Antigüedad y Cristianismo, III (1986), pp. 189-196.

DíAz, Pablo de la Cruz, "Regula Communis: monastic space and social context", en Hendrick Dey, Elizabeth Fentress (eds.), Western monasticism ante litteram. The spaces of monastic observance in Late Antiquity and the Early Middle Ages, Turnhout: Brepols, 2011, pp. 117-135.

DíAz, Pablo de la Cruz, "El eremitismo en la Hispania visigoda. Valerio del Bierzo y su entorno", en José Ángel García de Cortázar y Ruiz de Aguirre, Ramón Teja (coords.), El monacato espontáneo. Eremitas y eremitorios en el mundo medieval, Aguilar de Campóo: Fundación Santa María La Real, 2011, pp. 59-83.

Dierkens, Alain, "Réflexions sur le miracle au haut Moyen Âge", en Actes des congrès de la Société des historiens médiévistes de l'enseignement supérieur public. $25^{e}$ congrès, Orléans, 1994, pp. 9- 30. DOI 10.3406/shmes.1994.1648. URL www.persee.fr/web/revues/ home/prescript/article/shmes_1261-9078_1995_act_25_1_1648 [consultado el 30 de septiembre de 2014]

DAM, Raymond van, Leadership and community in Late Antique Gaul, Berkeley: California University Press, 1985.

DzIALOWSKI, Gustav von, Isidor und Ildefons als Literarhistoriker: Eine quellenkritische Untersuchung der Schriften «De uiris Illustribus» des Isidor von Sevilla und des Ildefons von Toledo, Münster: Heinrich Shöningh, 1898.

FontaINe, Jacques, "El De viris illustribus de san Ildefonso de Toledo: tradición y originalidad, Anales Toledanos, 3 (1971), pp. 59-97.

Fontaine, Jacques, "Education and learning", en Paul Fouracre (ed.), The New Cambridge Medieval History, I, Cambridge: Cambridge University Press, 2005, pp. 735-759. 
Galán SÁnchez, Pedro Juan, "El De viris illustribus de Ildefonso de Toledo o la modificación del género", Anuario de estudios filológicos, 15 (1992), pp. 69-80.

García Moreno, Luis Agustín, "Los monjes y monasterios en las ciudades de las Españas tardorromanas y visigodas", HABIS, 24 (1993), pp. 179-192.

García Moreno, Luis Agustín, "Disenso religioso y hegemonía política”, 'Ilu. Revista de Ciencias de las Religiones, 2 (1999), pp. 47-63.

GonzÁlez Blanco, Antonino, "El decreto de Gundemaro y la historia del siglo VII", Antigüedad y cristianismo, 3 (1986), pp. 159-170.

GuiAnce, Ariel, "Milagros y prodigios en la hagiografía altomedieval castellana", História Revista, 1-11 (2006), pp. 17-44.

LAUwers, Michel, "Le cimetière dans le Moyen Âge latin. Lieu sacré, saint et religieux", Annales. Histoire, Sciences Sociales, $5-54$ (1999), pp. 1047-1072.

Howard-Johnston, James; Hayward Paul, Antony (eds.), The cult of saints in Late Antiquity and the Middle Ages, Oxford: Oxford University Press, 1999.

KaPlan, Michel, (ed.), Le sacré et son inscription dans l'espace à Byzance et en Occident: Études comparées, París: Publications de la Sorbonne, 2001.

Martin, Céline, La géographie du pouvoir dans l'Espagne visigothique, París: Septentrión, 2003.

MARTIn, José Carlos, "El catálogo de los varones ilustres de Isidoro de Sevilla (CPL 1206): contenidos y datación”, Studia historica. Historia Antigua, 31 (2013), pp. 129-151.

MARTín Viso, Iñaki, “Organización episcopal y poder entre la Antigüedad Tardía y el Medioevo (siglos V- XI). Las sedes de Calahorra, Oca y Osma”, IBERIA, 2 (1999), pp. 151-190.

MARTín VISO, Iñaki, "Monasterios y redes sociales en el Bierzo altomedieval", Hispania: revista española de historia, 237-LXXI (2011), pp. 9-38.

MARTín VISO, Iñaki "The memory of holy men in Hispanic monasticism", Imago Temporis. Medium Aevum, VI (2012), pp. 165- 190.

Monreal Jimeno, Luis Alberto, "Centros eremíticos y semieremíticos en el valle del Ebro: aspectos metodológicos”, en José Ignacio de la Iglesia Duarte (coord.), II Semana de estudios medievales: Nájera 5 al 9 de Agosto de 1991, Logroño: Instituto de Estudios Riojanos, 1992, pp. 49-63.

Olmo Enciso, Lauro, "Ciudad y Estado en época visigoda: Toledo, la construcción de un nuevo paisaje urbano", en Alfonso García (coord.), Espacios urbanos en el occidente mediterráneo (s. VI- VIII), Toledo: Toletvm Visigodo, 2010, pp. 87-112.

Orlandis, José, Época visigoda (409-711), Madrid: Gredos, 1987.

RAPP, Claudia, Holy Bishops in Late Antiquity. The nature of christian leadership in an age of transition, Berkeley: University of California Press, 2005.

RIPOLL, Gisela, "Changes in the topography of power: from civitates to vrbes regiae in Hispania", en Richard Corradini, Max Diesenberger, Helmut Reimitz (eds.), The construction of communities in the early middle ages. Texts, resources and artefacts, Leiden: Brill, 2003, pp. 123-148.

Thompson, Edward Arthur, Los godos en España, Madrid: Alianza, 1971.

Uytfanghe, Marc van, "La Bible dans les Vies de saints mérovingiennes", Revue d'histoire de l'Église de France, 168-62 (1976), pp. 103-111. 
Velázquez SoRIANo, Isabel, La literatura hagiográfica: presupuestos básicos y aproximación a sus manifestaciones en la Hispania visigoda, Burgos: Fundación Instituto castellano y leonés de la Lengua, 2007.

WARD, Benedicta, Miracles and the medieval mind. Theory, record and event, 1000-1215, Aldershot: Scholar Press, 1987.

Ward, Benedicta, "Miracles in the Middles Ages", en Graham Twelftree (ed.), The Cambridge companion to miracles, Cambridge: Cambridge University Press, 2011, pp. 149-164.

Wood, Jamie, "Playing the fame game. Bibliography, celebrity and primacy in Late Antique Spain”, Journal of Early Christian Studies, 20-4 (2012), pp. 613-640. 